\title{
Yüksek Basınçlı Döküm Prosesinde Enjeksiyon Parametrelerine Bağlı Olarak Döküm Simülasyon
}

\author{
Murat KORU ${ }^{1 *}$, Orhan SERÇE ${ }^{1}$ \\ ${ }^{\text {I} S u ̈ l e y m a n ~ D e m i r e l ~ U ̈ n i v e r s i t e s i, ~ T e k n o l o j i ~ F a k u ̈ l t e s i, ~ E n e r j i ~ S i s t e m l e r i ~ M u ̈ h e n d i s l i g ̆ i, ~} 32260$ Isparta, \\ Türkiye
}

Received: 17.02.2015; Accepted: 05.06.2015

\begin{abstract}
Özet. Bu çalışmada, yüksek basınçlı döküm yöntemi ile üretimi gerçekleştirilen bir dişli kutusunun farklı termal ve dinamik parametrelere bağlı olarak Vulcan ve Flow3D simülasyon programları kullanılarak analiz işlemleri gerçekleştirilmiştir. Simülasyonlar sırasında kalıp sıcaklığı olarak 423 ve 573 K, döküm sıcaklığı olarak 953 ve 1053 $\mathrm{K}$, enjeksiyon ikinci faz hızı olarak 1,3 ve $5 \mathrm{~m} / \mathrm{s}$ ve ikinci fazın başlangıcı olarak dolum ağzı ve topuk kısımları belirlenmiştir. Bu parametreler kullanılarak iki programda toplam 48 adet simülasyon yapılmıştır. Simülasyonların sonuçları porozite açısından incelenmiş ve enjeksiyon parametrelerinin parçada oluşan poroziteye etkisi araştırılmıştır. Materyal ve metot kısmında detayları verilen dişli kutusu için optimum döküm parametreleri sunulmuştur. Tüm deneysel parametreler dikkate alındığında optimum şartlar, ikinci faz başlangıç noktası için dolum ağzı, ikinci faz hızı $2 \mathrm{~m} / \mathrm{s}$, döküm sıcaklığı 1053K ve kalıp sıcaklığı 573K olarak belirlenmiştir. Bu parametreler için porozite miktarı Vulcan'da \%2.72 ve Flow3D'de \%3.24 oranında gerçekleşmiştir. Elde edilen sonuçlara göre ideal enjeksiyon şartlarında porozite miktarında \%27 oranında azalma sağlanmıştır.
\end{abstract}

Anahtar Kelimeler: Yüksek basınçlı döküm, Döküm simülasyonu, Porozite, Enjeksiyon fazı

\section{Casting Simulation of High Pressure Die Casting Depend on Injection Parameters}

\begin{abstract}
In this study, a gearbox produced by high-pressure die casting method is analyzed depending on different thermal and dynamic parameters by Vulcan and Flow3D simulation soft wares. In the simulations, die temperature is taken as 423 and $573 \mathrm{~K}$, and casting temperature is taken as 953 and $1053 \mathrm{~K}$. In addition, Injection's second phase velocity is determined 1, 3 and $5 \mathrm{~m} / \mathrm{s}$ respectively. Moreover, filling gate and biscuit are determined as the start point of second phase. 48 simulations are totally performed using those parameters in those soft wares. Simulation outcomes are studied in terms of porosity as well as the effects of different injection parameters on the product porosity. Optimal casting parameters for the gearbox given its details in the material and methods section of the study are also presented. When all the experimental parameters are taken into consideration, optimal conditions are determined as such that Filling gate is for the second phase start point, second phase velocity is $2 \mathrm{~m} / \mathrm{s}$, casting temperature is $1053 \mathrm{~K}$ and die temperature is $573 \mathrm{~K}$. Porosity amount is $2.72 \%$ for Vulcan and $3.24 \%$ for Flow $3 \mathrm{D}$. According to the obtained results, porosity amount is decreased $27 \%$ in the ideal conditions.
\end{abstract}

Keywords: High-pressure die-casting, Casting simulation, Porosity, Injection phase

\section{GİRISs}

Yüksek Basınçlı döküm, karmaşık ve ince (3mm) cidarlı parçaların tam-yarı mamul bir şekilde üretilmesine imkân sağlayan ve endüstride yaygın olarak kullanılan bir üretim yöntemidir. Ayrıca yüksek üretim oranı ve düşük üretim maliyeti bu yöntemin avantajları arasındadır. Basınçlı döküm prosesi bir imalat yöntemi olmakla birlikte büyük oranda termal bir süreci kapsar. Bu

*Corresponding author. Email: muratkoru@ sdu.edu.tr 
nedenle döküm ve kalıptaki sıcaklık dağılımı parça kalitesini ciddi oranda etkilemektedir. Basınçlı dökümde termal analiz, kalıp ve döküm açısından pek çok zorluğu içermektedir. Bu nedenle günümüzde üretim sürecini etkileyen pek çok parametreyi (termal ve dinamik) dikkate alan ve optimum ürün elde edilebilmesine imkan sağlayan programlar kullanılmaktadır [1-5].

Simülasyon programları ile katılaşma, dolum, döküm-kalıp sıcaklık dağılımı, soğuk birleşme, son hava, akış hızları, mikro ve makro porozite gibi parametrelere bağlı simülasyonlar yapılabilmektedir. Böylece döküm hatalarını en az düzeye indirmek ve tek seferde başarılı bir üretim yapmak mümkün olabilmektedir [5,8-15].

Basınçlı döküm yönteminde, dinamik (faz hızları, faz geçiş noktaları), termal parametreler (döküm ve kalıp sıcaklığı) ile kalıp tasarımı (yolluk, dolum yüzeyi, hava cepleri, kalıp malzemesi ve yüzey kalitesi) üretilecek ürünün kalitesinde etkin rol oynamaktadır. Bu parametrelerin doğru seçilmesi optimum ürün elde edilmesi için önemlidir. Parametrelerin uygun seçilmemesi çekme boşlukları (makro porozite), gaz boşlukları (mikro porozite), soğuk birleşmeler, yapışma, tabakalaşma, pullanma, akış çizgileri, yüzey çöküntüleri, çekme çatlamaları, sert noktalar gibi pek çok istenmeyen hataya yol açmaktadır $[1,5,8,11-18]$.

Dökümü gerçekleştirilen alaşım katı haldeyken, sıvı hale oranla daha az yer kaplar, bunun sebebi katı haldeyken mikro taneciklerinin arasındaki bağların daha sıkı ve kısa olmasıdır. Bu durum çekme boşluklarının oluşmasına neden olabilir. Çekme boşlukları (makro porozite) genellikle parça içerisinde en son katılaşan, daha kalın cidarlı bölgelerde ve uzun süre sıcak kalan (hot spot) noktalarda meydana gelmektedir.

Kalıp boşluğunda var olan veya sıvı metal içinde çözünmüş gazların alaşımı ve kalıbı terk edememesi sonucu parça içinde veya yüzeyinde oluşan hatalara gaz boşluğu (mikro porozite) denilmektedir. Makro porozite düzensiz ve pürüzlü oldukları halde mikro porozite yuvarlak ve düzgündür. Hatalı kalıp tasarımı, hatalı enjeksiyon hızları ve ikinci faz başlangıç noktası, hatalı yağlayıcı kullanımı ve düzensiz katılaşma mikro porozite oluşumuna neden olmaktadır $[15,16]$.

Bu çalışmada, basınçlı döküm ile üretim yapan bir firmadan temin edilen dişli kutusu CAD programları aracılığıyla modellenmiş ve sonrasında VULCAN ve Flow3D döküm simülasyonu programlarına aktarılmıştır. Simülasyon programlarında gerekli simülasyon işlemleri gerçekleştirilerek optimum enjeksiyon dinamik ve termal parametreleri belirlenmiştir. Kullanılan enjeksiyon dinamik parametreleri birinci faz hızı $0.4 \mathrm{~m} / \mathrm{s}$, ikinci faz hızları ise 1,3 ve $5 \mathrm{~m} / \mathrm{s}$ olmak üzere üç farklı değerde seçilmiştir. Ayrıca ikinci fazın başlangıç noktası da iki farklı şekilde seçilerek etkisi incelenmiştir. Kalıp sıcaklığı 423 ve 573K, döküm sıcaklığı 953 ve $1053 \mathrm{~K}$ için ikişer farklı değerde simülasyon işlemleri tekrarlanmıştır. Farklı döküm şartlarında Vulcan ile 24 ve Flow3D ile 24 adet olmak üzere toplamda 48 adet simülasyon işlemi gerçekleştirilmiştir. Simülasyonlardan dolum süresi, katılaşma süresi, dolum hızları, makro ve mikro porozite sonuçları elde edilmiştir. Elde edilen sonuçlar incelenerek optimum enjeksiyon parametreleri belirlenmiştir.

Yapılan çalışmalar sonucunda kalıp ve döküm sıcaklıklarının yükseltilmesi ile porozite miktarları azalmaktadır. Sonuçlar toplu olarak değerlendirildiğinde ise incelenen dişli kutusu parçası için optimum enjeksiyon parametreleri, döküm sıcaklığı $1053 \mathrm{~K}$, kalıp sıcaklığı $573 \mathrm{~K}$, ikinci faz hızı $2 \mathrm{~m} / \mathrm{s}$ ve ikinci fazın başlangıç noktası dolum ağzı olarak belirlenmiştir. 


\section{MATERYAL VE METOD}

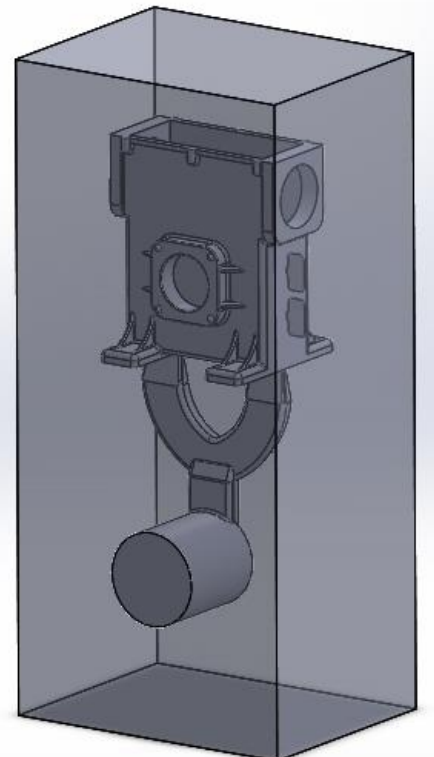

CAD Programından Alınan Görüntü

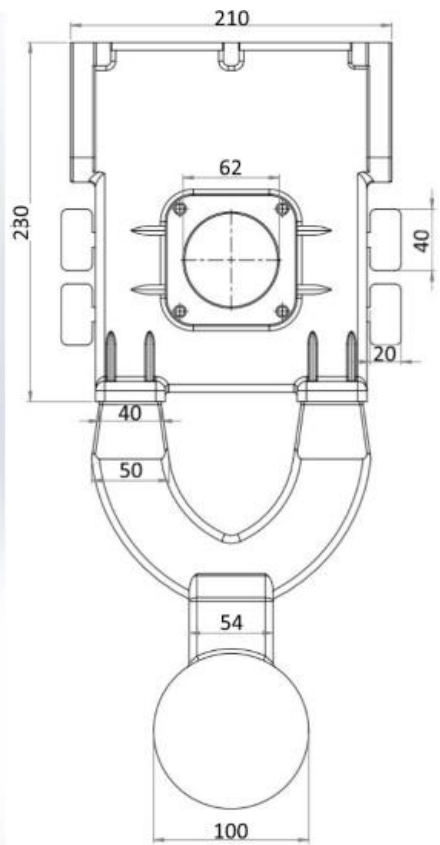

Ön Görünüș

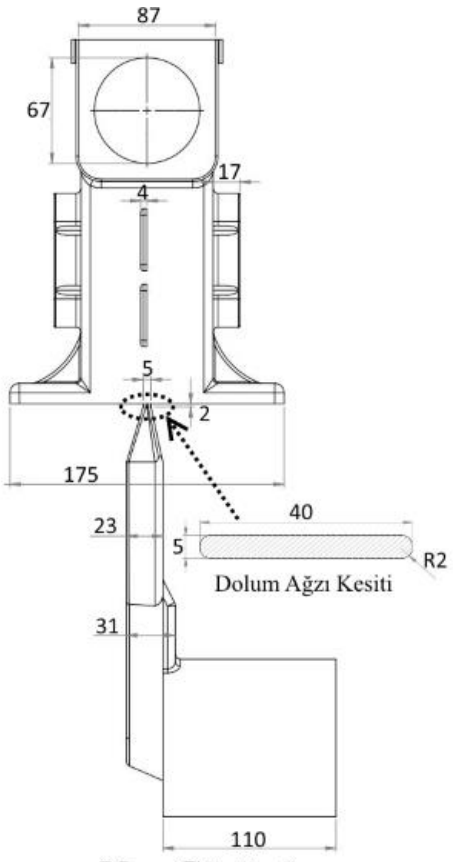

Yan Görünüş

Şekil 1. Simülasyon modelinin CAD programından alınan görüntüsü, ön ve yan görünüşü ile dolum ağzı.

Simülasyonu yapılacak parçanın modeli CAD programında orijinal ölçülerine sadık kalınarak tasarlanmıştır. Tasarımı yapılan parçanın ve kalıbın CAD programından alınmış görüntüsünün yanı sıra ölçüleri ön ve yan görünüşleri ile dolum ağzı kesiti Şekil 1'de sunulmuştur.

Modelin tasarımı tamamlandıktan sonra Vulcan programına aktarımı için IGES, Flow3D programına aktarımı için ise STL formatları kullanılmıştır. Simülasyon programların ilk olarak kalıp ve döküm malzemesi tanımlanmıştır. Bu çalışmada kalıp için H13 sıcak iş takım çeliği ve döküm için A380 alüminyum alaşımı kullanılmıştır. Kullanılan kalıp ve döküm malzemesinin özellikleri Tablo 1'de verilmiştir.

Tablo 1. A380 döküm malzemesinin ve H13 kalıp malzemesinin termofiziksel özellikleri.

\begin{tabular}{llc}
\hline Malzeme & H13 & A380 \\
\hline Özgül ısı (c), J/kg.K & $435.37+0.2 \mathrm{~T}$ & 1100 \\
Yoğunluk $(\rho), \mathrm{kg} / \mathrm{m}^{3}$ & $766.86-0.3174 \mathrm{~T}$ & $-0.8926 \mathrm{~T}+3337.66$ \\
Isı iletkenlik katsayısı (k), W/mK & $0.00029 \mathrm{~T}-26.85$ & $-0.1144 \mathrm{~T}+200,997$ \\
\hline T Sicaklık $(\mathrm{K})$, Ergime Sıcaklığı 921K, Katılaşma S1caklığı 787K & \\
\hline
\end{tabular}

Kalıp ve döküm malzemesinin tanımlanmasından sonra enjeksiyon termal ve dinamik parametrelerinin tanımlanmasına geçilmiştir. Bu aşamada yerçekimi ivmesi ve yönü, ortam sıcaklığı, döküm ve kalıp sıcaklığı, birinci ve ikinci faz hızları, enjeksiyon ikinci fazına geçiş noktası ve üçüncü fazın basıncı tanımlanmıştır. Bu çalışmada kullanılan enjeksiyon dinamik ve termal parametreleri Şekil 2'de toplu olarak görülmektedir. Bu şekilde görüleceği üzere 
enjeksiyon ikinci fazının başlangıcı için iki farklı nokta belirlenmiştir. Birinci durumda (a) ergimiş metal kovan kısmını tamamladıktan sonra yolluğun topuk kısmını geçtiği anda başlayacak şekilde seçilmiştir. İkinci durumda (b) ise ergimiş metal topuk kısmını geçtikten sonra da birinci faz ile süpürülmeye devam edilmekte ve dolum ağzına ulaştıktan sonra ikinci faz başlamaktadır. Bu durum Şekil 3'de gösterilmiştir.

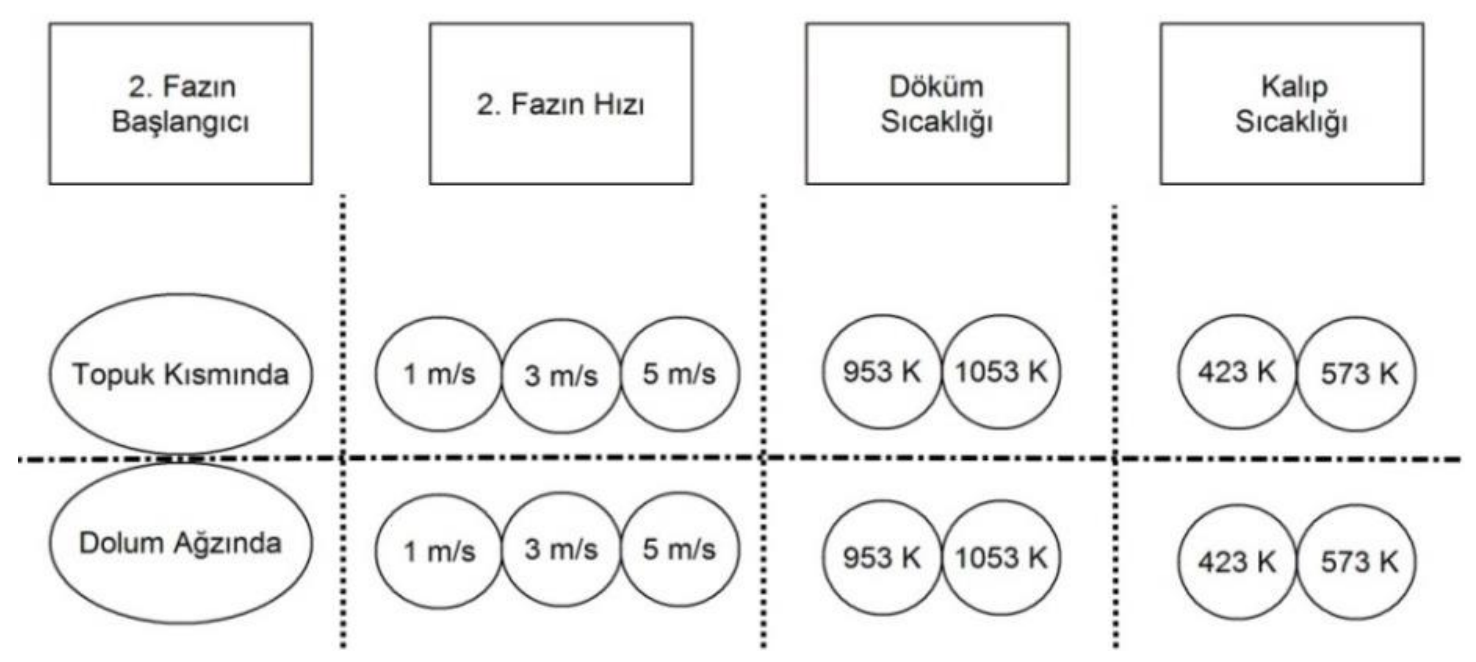

Şekil 2. Kullanılan enjeksiyon termal ve dinamik parametreleri.

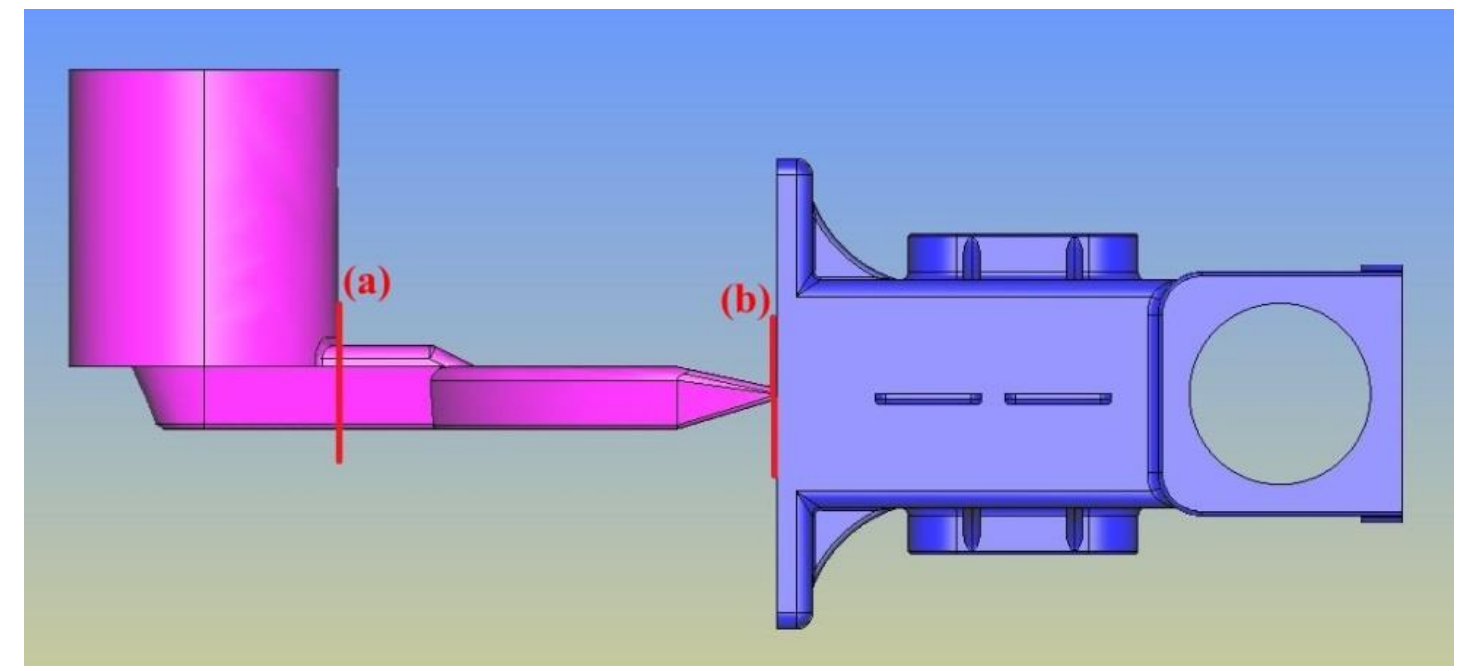

Şekil 3. Seçilen 2.faz başlangıç noktaları. (a) topuk ve (b) dolum ağzı.

Parametre tanımlamadan sonra, programların sonlu elemanlar metodu (FEM) ile hesaplama yapabilmesi için mesh oluşturma işlemine geçilmiştir. Vulcan simülasyon programında kalıp, parça ve yolluğun toplamında 611016 mesh ve mesh için 110798 nokta oluşturulmuştur. Kullanılan mesh tipi ise üçgen meshdir. Mesh oluşturma sırasında dikkat edilen husus ise modelin özellikle dairesel kısımlarının ve köşelerinin geometrisinin mesh elemanları ile sağlanmış olmalıdır (Şekil 4). 


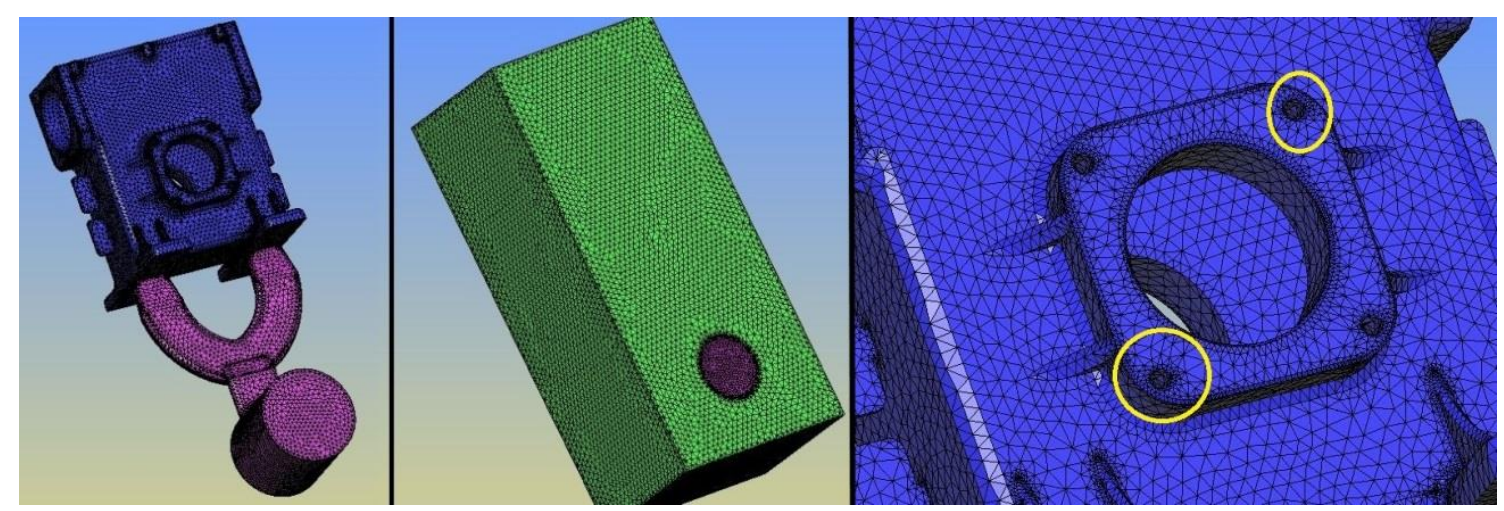

Şekil 4. Vulcan programında oluşturulan mesh.

Flow3D programında ise mesh oluşturulacak kısmın sınırları seçilmiş ve otomatik olarak mesh yapılmıştır. Flow3D programında bu model için toplamda 4595400 mesh oluşturulmuştur (Şekil 5). Şekil incelendiğinde parçayı kafes içine alan çizgiler ile ayrılmış kısım mesh oluşturulacak yerin sınırlarını belirlemektedir. Aynı zamanda bu kısımlar kalıbı da ifade etmektedir. Şekildeki mavi renkli kısım ise piston olup, kovan kısmı simülasyonda tanımlanarak ergimiş metalin kovan içindeki hareketinin de hesaplamaya dâhil edilmesi sağlanmıştır. Bu tanımlamaların ardından Flow3D programında hesaplamaların yapılabilmesi için gerekli olan formüller (Physics modülleri) belirlenmiştir.

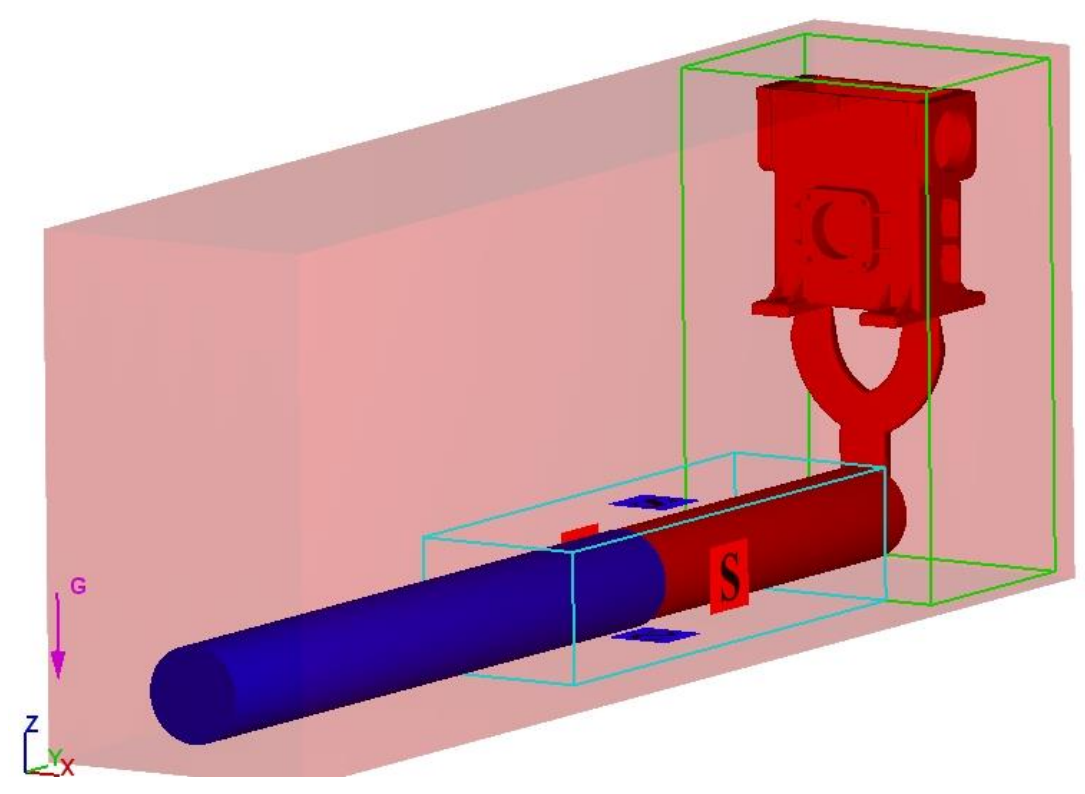

Şekil 5. Flow3D programından alınan mesh.

Dolum simülasyonu için "Physics" modülleri Air Entrainment (dolum sırasında parça içinde hapsolacak havanın hesaplanması için kullanılan formülleri içerir), Bubble and Phase Change (dolum sırasında kalıp içerisinde sıkışan havanın nasıl davranacağının seçildiği kısım), default ayarlarında bırakıldığında hava kalıp içerisinde sıkışsa dahi bir basınç yükselmesine sebep olmamaktadır. Bu sebeple çalışmada "Adiabatic Bubble” seçeneği kullanılmıştır. Bu sayede hava sıkıştıkça basıncı artarak gerçeğe daha yakın sonuçların elde edilmesi sağlanacaktır. Gravitiy and 
Non-Intertial Reference Frame; yerçekimi ivmesinin yönünü ve miktarının girilmesi ile hesaplamalara katılması için kullanılan seçenektir. Viscosity and Turbulance; akışkanın viskozitesinin ve türbülanslı akışın etkisinin hesaplamalara katılması amacıyla kullanılan seçenektir. Defect Tracking; ergimiş metaldeki oksitlenmeleri hesaba dâhil etmeyi sağlayan seçenektir. Moving and Simple Deforming Objects; model üzerinde oluşturulan pistonun hareketini hesaba ekleyen seçenektir. Heat Transfer; dolum sırasında ergimiş metal ile kalıp arasındaki 1sı transferini hesaplamada kullanılan formülleri aktif hale getiren seçenektir. Katılaşma simülasyonu sırasında kullanılan modüller ise şunlardır, Gravitiy and Non-Intertial Reference Frame. Heat Transfer; ergimiş metalin soğuması sırasında kalıp ile arasında gerçekleşen 1sı transferinin hesaplanması amacıyla kullanılmaktadır. Solidification; katılaşma için gerekli hesaplamaların (Faz değişimi, Porozite oluşumu) yapılmasında kullanılan formülleri aktif hale getirmektedir.

\section{BULGULAR}

\subsection{Dolum Süreleri}

Basınçlı dökümde ikinci faz hızı kalıbın dolum şeklini ve süresini etkileyen en önemli parametredir. Ergimiş metal birinci fazda dolum ağzına yavaşça yaklaştırılır ve ikinci fazda hızlı bir şekilde kalıp boşluğuna doldurulur. Bu çalışmada ikinci faz hızı olarak üç farklı değer belirlenmiştir. Bu değerler dolumun yavaş, orta ve hızlı gerçekleşmesini sağlayarak aradaki farkın belirlenmesi amacıyla 1,3 ve $5 \mathrm{~m} / \mathrm{s}$ olarak tanımlanmıştır.

Vulcan ve Flow3D programlarından alınan, enjeksiyon ikinci faz hızı, ikinci faz başlangıç noktası ve dolum süresi arasındaki ilişkiyi gösteren simülasyon sonuçları Şekil 6'da verilmiştir. Elde edilen verilere göre 1 ve $3 \mathrm{~m} / \mathrm{s}$ ikinci faz hızları arasında yaklaşık olarak 0.11 saniyelik fark olduğu halde 3 ve $5 \mathrm{~m} / \mathrm{s}$ ikinci faz hızları için farkın 0.05 saniye civarına düştüğü görülmektedir. $\mathrm{Bu}$ durumun nedeni ikinci faz hızının artmasına karşın dolum ağzı alanının bu hızı karşılayacak kapasitede olmayışıdır.
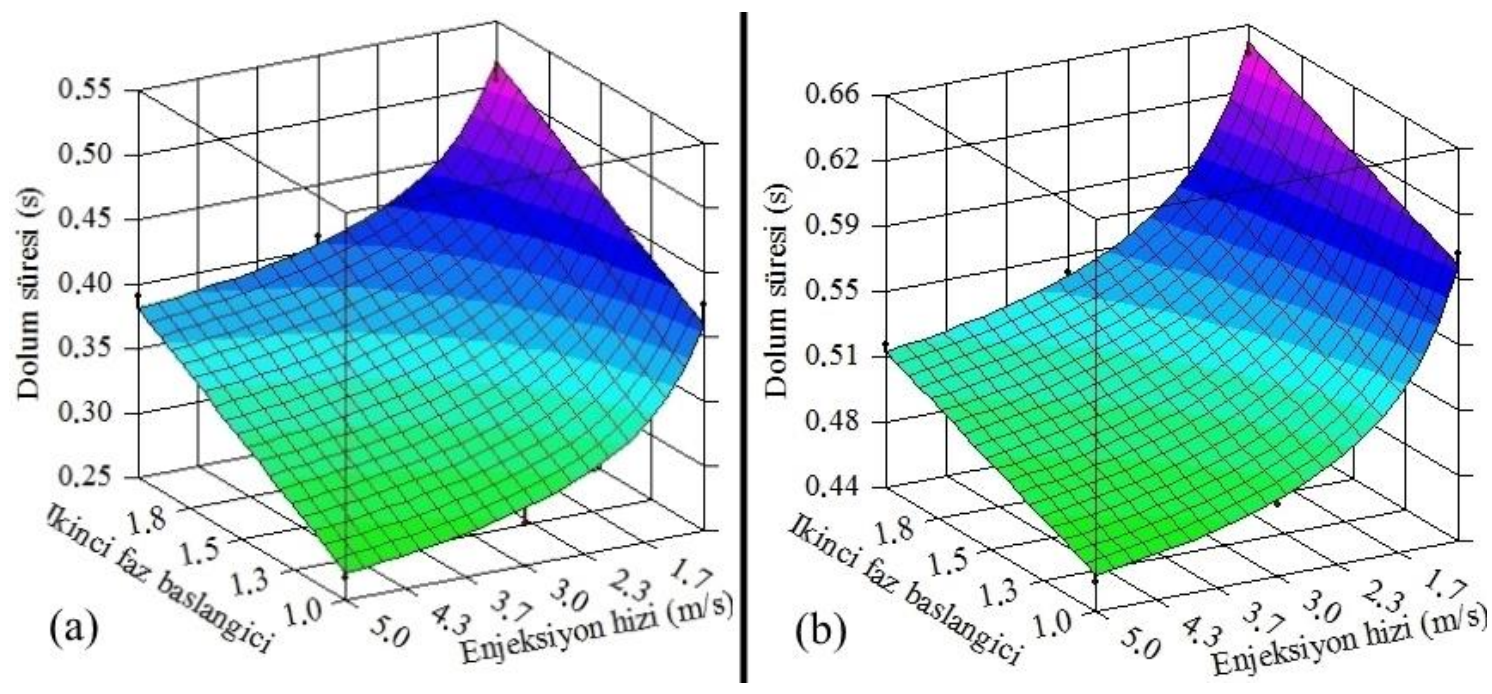

Şekil 6. Dolum süresi sonuçları (a) Vulcan, (b) Flow3D. 
Şekil 6 incelendiğinde dolumun en hızlı gerçekleştiği durumlar ikinci fazın $5 \mathrm{~m} / \mathrm{s}$ hızında ve ikinci fazın başlangıç noktasının topukta seçilmiş olduğu durumlardır. Yani ikinci faz süre bakımından daha erken başladığından dolum da erken bitmektedir. Dolumun en yavaş olduğu durumlar ise ikinci fazın $1 \mathrm{~m} / \mathrm{s}$ ve ikinci fazın dolum ağzından başladığ 1 durumlardır.

Dolum süreleri bakımından Vulcan ile Flow3D programı farklı sonuçlar vermiştir. Bunun sebebi Vulcan programında ergimiş metal topuk kısmından girilen hız değerlerine bağlı olarak dolmaktadır. Flow3D programında ise kovan ve piston kısımları modellenerek hesaplamaya katılmakta dolayısıyla dolum süresi uzamaktadır.

Şekil 6 Flow3D sonuçları açısından incelendiğinde dolum sürelerine sadece ikinci faz hızının etki ettiği görülmektedir. Diğer döküm parametreleri değiştirilmesine rağmen dolum süresinde herhangi bir değişiklik olmamıştır. Flow 3D programında ikinci faz hızı 1'den $3 \mathrm{~m} / \mathrm{s}^{\prime} y e$ yükseltildiğinde dolum süresi yaklaşık olarak 0.12 s. kısalmıştır. Hızın 3 'den $5 \mathrm{~m} / \mathrm{s}$ 'ye yükseltildiğinde ise sadece 0.03 saniyelik bir değişim olmuştur. Bu durum her iki simülasyon programında da dolum süreleri için benzer bir eğilimi ortaya koymuştur. Bu benzerlik dolum ağzı tasarımının doğru ve akışın istenen hızda olmasını sağlamıştır.

\subsection{Katılaşma Süreleri}

Şekil 7'de Vulcan ve Flow3D programlarından alınan katılaşma süreleri verilmiştir. Vulcan programından alınan sonuçlar incelendiğinde en hızlı katılaşma kalıp sıcaklığının $423 \mathrm{~K}$ ve döküm sıcaklığının 953K olduğu durumlarda gerçekleşmiştir (yaklaşık $9.5 \mathrm{~s}$.).

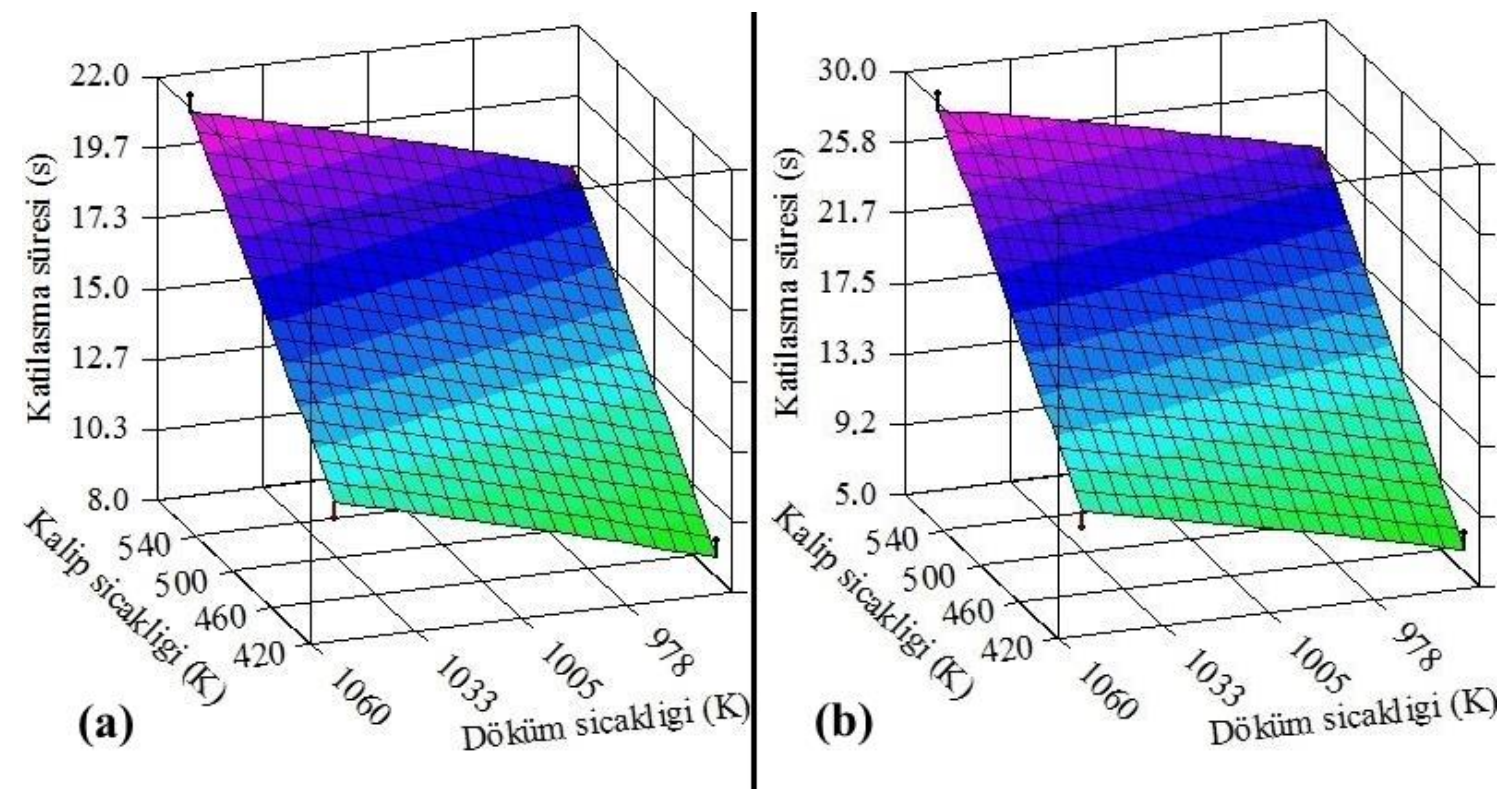

Şekil 7. Katılaşma süresi sonuçları (a) Vulcan, (b) Flow3D.

Katılaşmanın en uzun olduğu parametreler ise kalıp sıcaklığının 573K ve döküm sıcaklı̆̆ının 1053K olduğu (yaklaşık 21.5 s.) durumda gerçekleşmiştir. Döküm sıcaklığının 953K'den 1053K'e çıkartılması sonucunda katılaşma süresinde yaklaşık olarak 2.5 saniyelik bir artış olmuştur. Kalıp sıcaklığının 423K'den 573K'e yükseltildiği durumlarda ise katılaşma süresindeki artış miktarı daha fazla olmaktadır (yaklaşık 7 s.). Bu sonuçlara göre kalıp sıcaklığı katılaşma süresini ciddi oranda etkilemektedir. 
Şekil Flow3D açısından incelendiğinde kalıp sıcaklığının 423K olduğu durumlarda döküm sıcaklığının 100K artırılması katılaşma süresini 4 saniye artırırken, kalıp sıcaklığının 573K olduğu durumlarda döküm sıcaklığındaki artış katılaşma süresini 8 saniye artırmıştır. Döküm sıcaklıkları sabit tutulup kalıp sıcaklığındaki artışlar incelendiğinde ise farkların daha büyük olduğu görülmektedir. Döküm sıcaklığının 953K olduğu durumlarda kalıp sıcaklığı artırıldığında katılaşma süresi 8 saniyeden 25 saniye civarına yükselmiştir. Bu durum döküm sıcaklığının 1053 $\mathrm{K}$ olduğu durumda da benzer şekilde görülmektedir.

İki simülasyon programından alınan sonuçlar karşılaştırıldığında ise kalıp sıcaklığının 453K ve döküm sıcaklığının 953K olduğu durumlarda katılaşmanın Flow3D sonuçlarında yaklaşık 1-2 saniye daha erken gerçekleşmiştir. Kalıp sıcaklığının aynı döküm sıcaklığının ise 1053K olduğu durumda ise benzer sonuçlar elde edilmiştir. Kalıp sıcaklığının 573K olduğu durumda ise döküm sıcaklığının her iki durumu içinde Flow3D programından alınan sonuçlar yaklaşık 5-6 saniye daha uzun sürmüştür.

\subsection{Dolum Hizları}
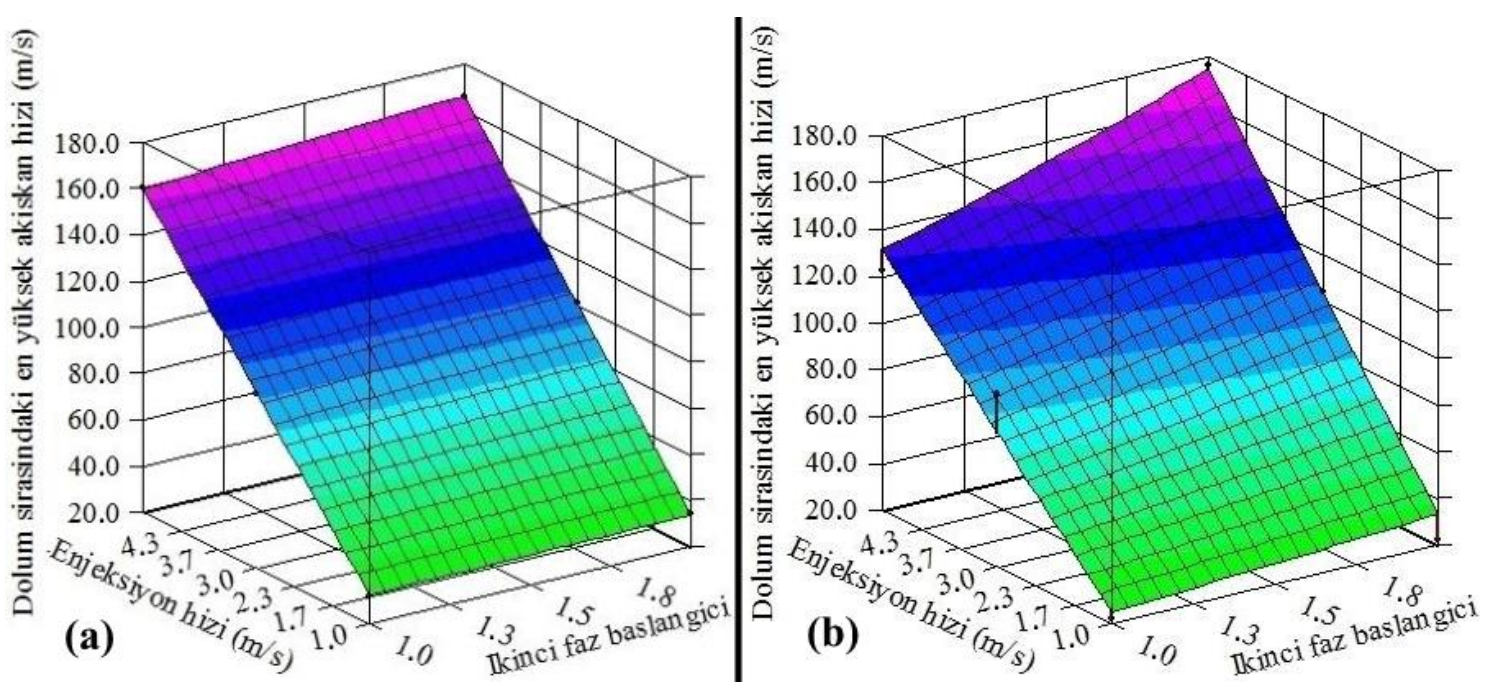

Şekil 8. Dolum sırasında oluşan en yüksek akış hızları (a) Vulcan, (b) Flow3D.

Şekil 8'de Vulcan ve Flow3D programlarından elde edilen, ikinci faz hızlarına bağlı olarak dolum ağzında oluşan maksimum akışkan hızları görülmektedir. Ortalama olarak $1 \mathrm{~m} / \mathrm{s}$ ikinci faz hızında maksimum akışkan hızı $32 \mathrm{~m} / \mathrm{s}, 3 \mathrm{~m} / \mathrm{s}^{\prime}$ de $100 \mathrm{~m} / \mathrm{s}$ ve $5 \mathrm{~m} / \mathrm{s}^{\prime}$ de ise $180 \mathrm{~m} / \mathrm{s}$ olarak hesaplanmıştır. Ergimiş metalin dolum ağzından geçişi sırasındaki hızının 30-60 m/s civarında olması ideal kabul edilmektedir [18]. Sonuçlardan da anlaşılabileceği gibi 3 ve 5m/s ikinci faz hızlarında akışkanın ulaştığı maksimum hız oldukça yüksek bir değerdedir. Bunun yanı sıra $1 \mathrm{~m} / \mathrm{s}$ ikinci faz hızında ise maksimum hızın istenen değerlerin altında kaldığı söylenebilir.

Şekil Flow3D sonuçları açısından incelendiğinde ise Vulcan ile benzer sonuçlar verdiği görülmektedir. Dolum sırasındaki en yüksek akışkan hızları dolum ağzında gerçekleşmektedir. Bu sebeple en fazla aşınma bu bölgede olmaktadır. Şekil 8'de ikinci faz hızının yükselmesi ile birlikte bu bölgedeki akışkan hızı da yükselmektedir. $1 \mathrm{~m} / \mathrm{s}$ için bakıldığında dolum yüzeyinde oluşan maksimum akış hızının dolum ağzı ve topukta başlatılan faz başlangıç noktaları için 
yaklaşık $22 \mathrm{~m} / \mathrm{s}$ değerine ulaştı̆̆ı görülmektedir. Bu değer dolum yüzeyinde istenen optimum değer aralığına kıyasla düşük kalmaktadır. 3 ve $5 \mathrm{~m} / \mathrm{s}$ 'lik ikinci faz hızları açısından şekil incelendiğinde ise dolum yüzeyindeki hızların en az $90 \mathrm{~m} / \mathrm{s}$ ve üzerinde olduğu görülmektedir. $\mathrm{Bu}$ değerler ise istenen optimum dolum ağzı hızı aralığına kıyasla yüksek kalmaktadır. Bu nedenle 3 ve $5 \mathrm{~m} / \mathrm{s}$ 'lik ikinci faz hızlarında kalıbın beklenen süreden daha önce aşınması muhtemeldir.

\subsection{Mikro Porozite}

Mikro porozite problemi kalıp dolumu sırasında akışkan içerisine sıkışan havadan ve katılaşma sırasında çıkan gazların parça içerisinde sıkışmasından kaynaklanmaktadır. Şekil 9'da her iki programdan da alınan mikro porozite sonuçlarının görseli bulunmaktadır. Elde edilen sonuca göre mikro porozite oluşumu en çok parçanın gövde kısmında meydana gelmektedir. Yapılan incelemelerde bu durumun denenen her parametre kombinasyonu için aynı olduğu görülmüş̧ür.
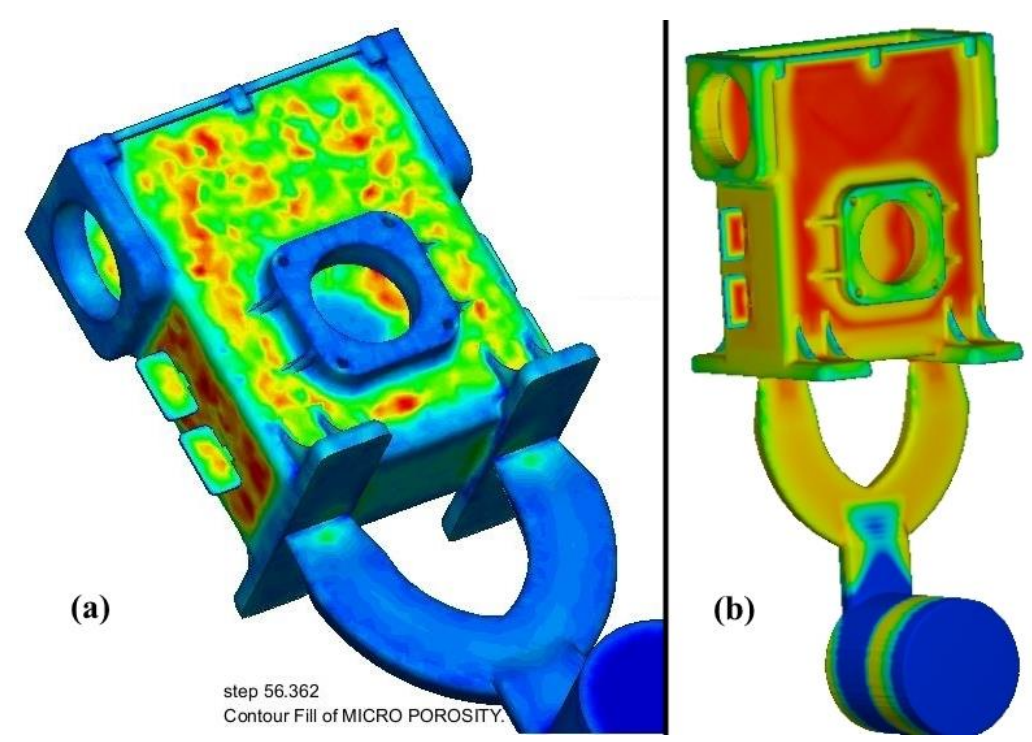

Şekil 9. Vulcan ve Flow3D programından alınan mikro porozite sonucu.

Şekil 10'da Vulcan programından alınmış mikro porozite sonuçları grafik üzerinde gösterilmiştir. (a) ikinci fazın başlangıcının topuk kısmı ve döküm sıcaklığının $953 \mathrm{~K}$ olduğu durumu (b) durumu ise $1053 \mathrm{~K}$ olduğu durumu göstermektedir. (c) grafiği ikinci fazın başlangıcının dolum ağzında ve döküm sıcaklığının $953 \mathrm{~K}$ olduğu durumu (d) grafiği sıcaklığın $1053 \mathrm{~K}$ olduğu durumu göstermektedir. 


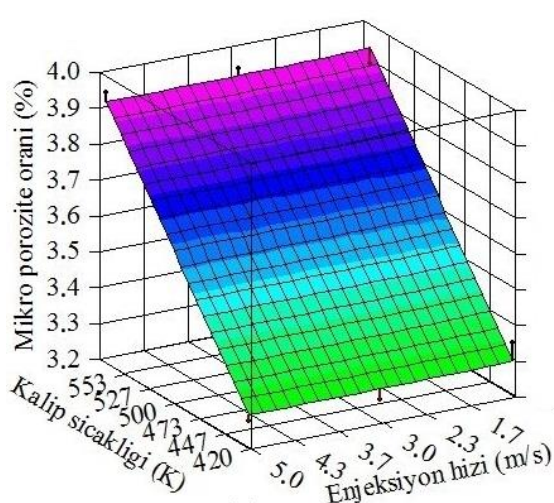

(a)

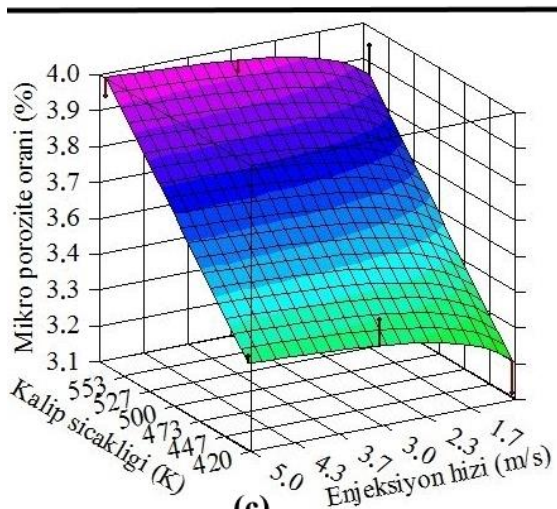

(c)

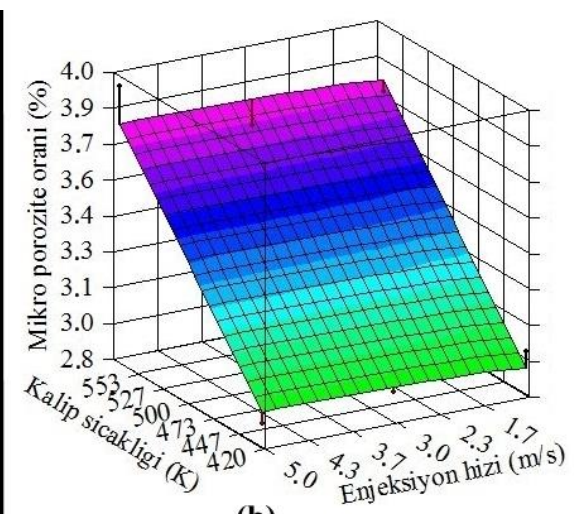

(b)

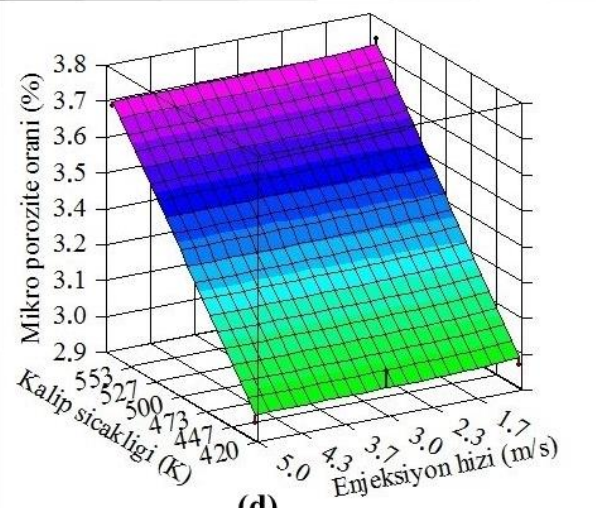

(d)

Şekil 10. Vulcan programından alınan mikro porozite sonuçları.

Şekil incelendiğinde döküm sıcaklığının 953K'den 1053K'e artırılması mikro porozitenin azalmasına olumlu yönde etki etmektedir. Bunun yanı sıra kalıp sıcaklığının $423 \mathrm{~K}$ 'den $573 \mathrm{~K}$ 'e yükseltilmesi ise porozite sonucuna olumsuz yönde etki etmiştir. Diğer parametreler açısından incelendiğinde ise sonuçların neredeyse birbirleri ile aynı olduğu görülmektedir. $\mathrm{Bu}$ sebeple seçilen parametreler arasında döküm ve kalıp sıcaklıkları mikro porozite oranına doğrudan etki etmektedir. Mikro porozitenin en az olduğu durum ise döküm sıcaklığının 1053K ve kalıp sıcaklığının $423 \mathrm{~K}$ olduğu durumlardır.

Sonuçlar yüzdesel olarak irdelendiğinde ise, kalıp sıcaklığının 573K ve döküm sıcaklığının 953K olduğu duruma nazaran kalıp sıcaklığının 423K ve döküm sıcaklığının 1053K olduğu durumda porozite miktarında \%27'lik bir azalma gözlemlenmiştir. Kalıp sicaklığının 423K'de sabit olduğu döküm sıcaklığının 953K'den 1053K'e arttırıldığ 1 durumda ise mikro porozite miktarında \%14'lük bir azalma olmuştur.

Flow3D programından alınan sonuçlar ise Şekil 11'de verilmiştir. Şekilde (a) ikinci fazın başlangıcının topuk kısmında ve döküm sıcaklığının $953 \mathrm{~K}$ olduğu durumu (b) durumu ise $1053 \mathrm{~K}$ olduğu durumu göstermektedir. (c) grafiği ikinci fazın başlangıcının dolum ağzında ve döküm sıcaklığının $953 \mathrm{~K}$ olduğu durumu (d) grafiği sıcaklığın $1053 \mathrm{~K}$ olduğu durumu göstermektedir. 


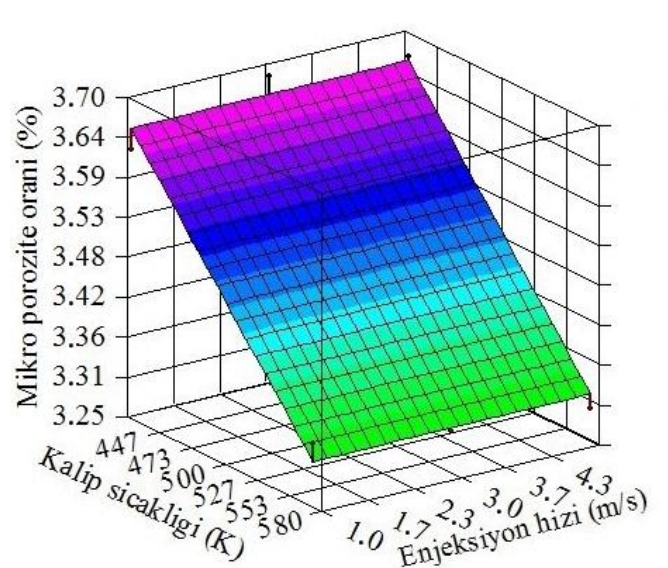

(a)

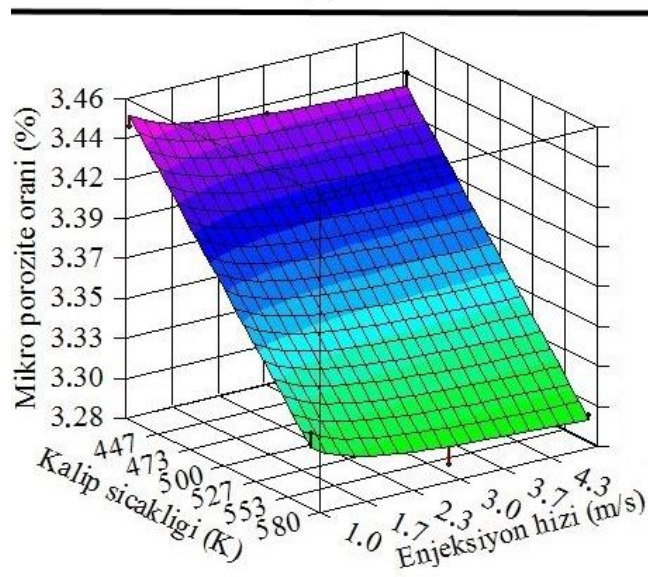

(c)

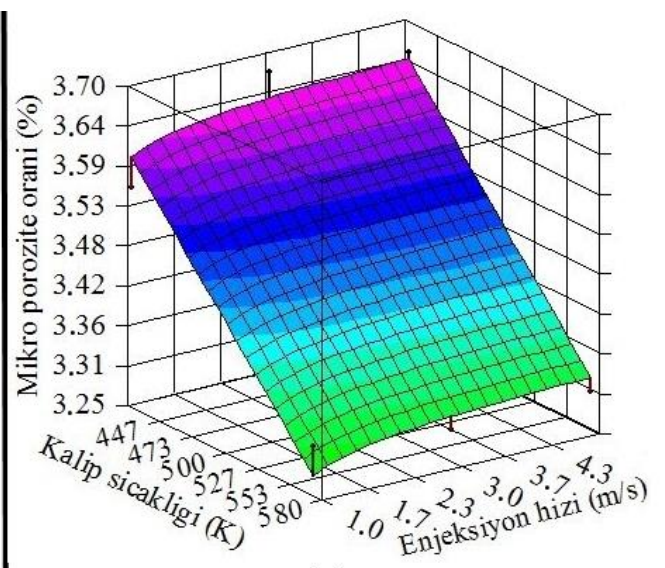

(b)

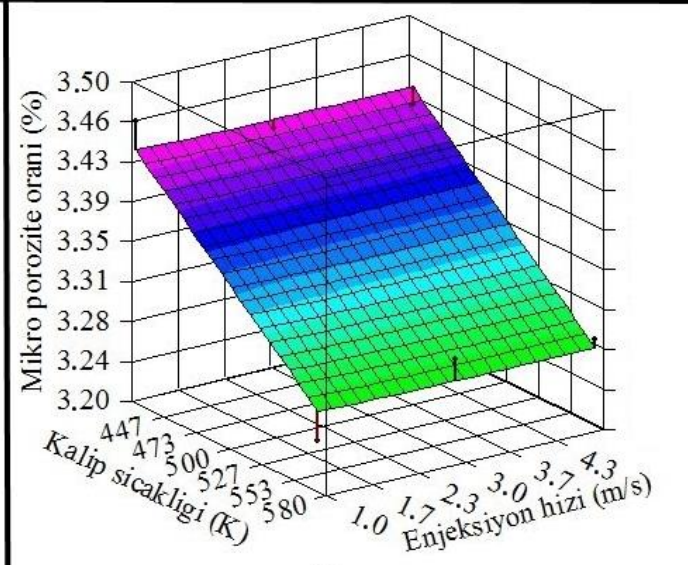

(d)

Şekil 11. Flow3D programından alınan mikro porozite sonuçları.

Sonuçlar incelendiğinde mikro porozite oluşumu daha çok termal parametrelere bağlıdır. Mikro porozite oluşumunun en az olduğu durumlar ikinci fazın 1m/s, kalıp sıcaklığının $573 \mathrm{~K}$ ve döküm sıcaklığının 1053K olduğu durumlardır. Bu açıdan iki programın sonuçları farklılık göstermektedir. Vulcan programında kalıp sıcaklığı arttığında daha yüksek porozite sonuçları elde edilirken Flow3D programına göre kalıp sıcaklığının artırılması porozite oluşumunu olumlu yönde etkilemektedir.

\subsection{Makro Porozite}

Makro porozite, katılaşma sırasında ergimiş alüminyumun çekmesi sonucu parçanın içerisinde oluşan boşluklardır.

Vulcan simülasyon programından elde edilmiş sonuçlar (Şekil 12) kıyaslandığında, döküm sıcaklığının ve kalıp sıcaklığının arttırılması ise makro porozitenin azaldığı gözlemlenmiştir. Faz açısından incelendiğinde faz başlangıç noktasının dolum ağzında seçilmesi daha iyi sonuçlar vermiştir. Ayrıca faz hızının $3 \mathrm{~m} / \mathrm{s}$ olduğu durumlarda makro porozite açısından daha iyi sonuçlar vermektedir. 
Makro porozite için en iyi sonuçları veren parametreler şöyledir; kalıp sıcaklığı $423 \mathrm{~K}$, döküm sıcaklığı $1053 \mathrm{~K}$, ikinci faz başlangıç noktası dolum ağzında ve ikinci faz hızı $3 \mathrm{~m} / \mathrm{s}$ şeklindedir. En kötü sonuçlar ise kalıp yüzey pürüzlülüğ̈̈ yüksek, kalıp sıcaklığı $423 \mathrm{~K}$, döküm sıcaklığg 953 $\mathrm{K}$, ikinci faz hızı $1 \mathrm{~m} / \mathrm{s}$ ve ikinci fazın başlangıcı topuk kısmında seçilmiştir. Şekil 10'da en iyi makro porozite sonuçları ile en kötü makro porozite sonuçları verilmiştir. Enjeksiyon parametrelerinin doğru seçilmesinin makro porozite oluşumunu büyük ölçüde azalttığ1 görülmektedir.

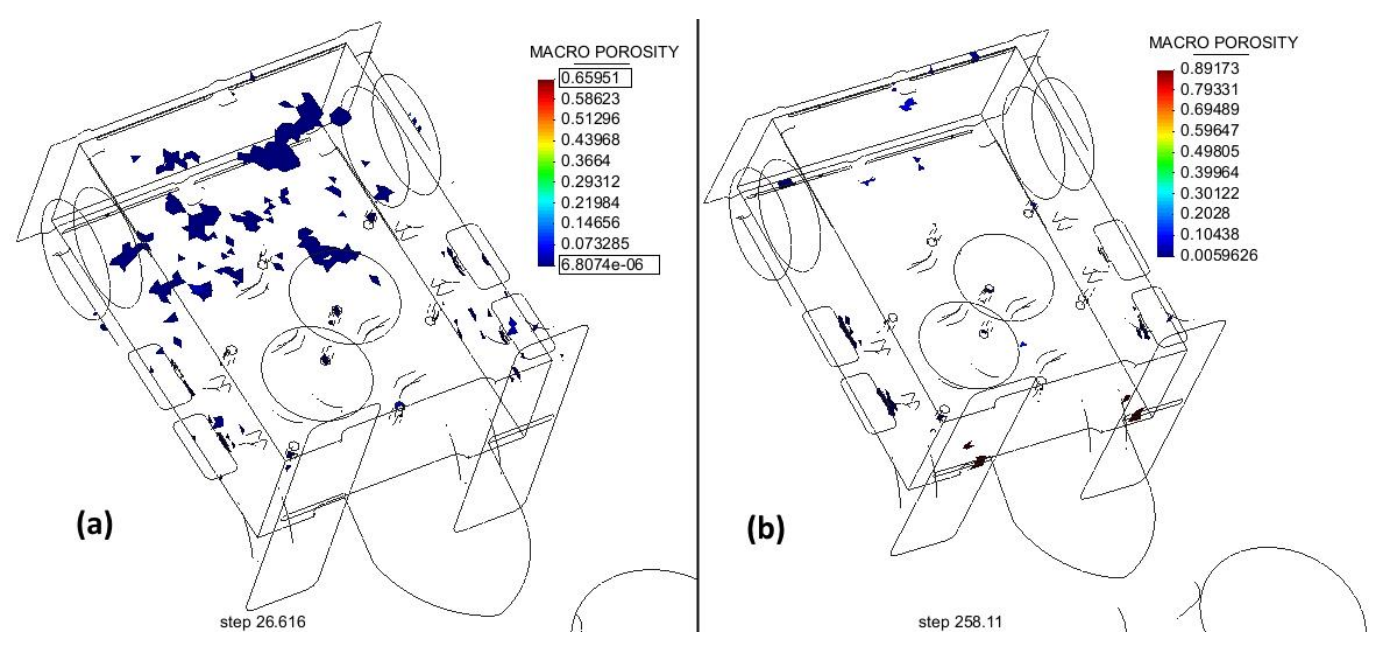

Şekil 12. Vulcan programından alınan en iyi (b) ile en kötü (a) makro porozite sonuçlarının karşılaştırılması.

\section{TARTIŞMA VE SONUÇ}

Bu çalışmada basınçlı dökümde kalıp sıcaklığının, döküm sıcaklığının, ikinci faz başlangıç noktası ve ikinci faz hızının mikro ve makro porozite oluşumuna etkisi incelenmiştir. Elde edilen sonuçlar şu şekilde özetlenebilir;

1. Döküm sıcaklığının 953K'den $1053 \mathrm{~K}$ 'e yükseltilmesi ile porozite oluşumu azalmıştır. Sonuçlar Jin vd. [18] ile paralellik göstermektedir.

2. Kalıp sıcaklığının yükselmesi ile iki programdan birbirinden farklı sonuçlar elde edilmiştir. Vulcan programına göre 423K kalıp sıcaklığı porozite açısından daha olumlu sonuçlar verirken, Flow3D programı porozite açısından 573K kalıp sıcaklığında daha uygun sonuçlar vermiştir.

3. İkinci faz hızı olarak 3 ve $5 \mathrm{~m} / \mathrm{s}$ hızları hem porozite oluşumu açısından kötü sonuç vermiştir hem de dolum ağzında kalıba zarar verebilecek derecede yüksek akışkan hızlarına sebep olmuştur. $1 \mathrm{~m} / \mathrm{s}$ hızı ise porozite açısından en iyi sonuçları vermesine karşın dolum ağzında istenen akış hızını sağlayamamıştır. Bu nedenle, çalışmadaki model için optimum ikinci faz hızı olarak $2 \mathrm{~m} / \mathrm{s}$ hızı belirlenmiştir. İkinci faz hızına bağlı olarak elde edilen sonuçlar Jin vd. [18,19] ve Verran vd. [1] ile benzerlik göstermektedir.

4. İkinci fazın başladığı nokta olarak topuk ve dolum ağzı kısımları karşılaştırıldığında, ikinci fazın dolum ağzında başladığı durum porozite oluşumunu düşürmüştür. Bu nedenle ikinci fazın dolum ağzında başlatılması kaliteli parça üretimi açısından iyi sonuçlar verecektir.

5. Her iki simülasyon programı ile yapılan simülasyonlardan elde edilen porozite sonuçları kullanılarak çoklu regresyon yöntemi ile oluşturulan denklemler (1) Vulcan programının ve (2) Flow3D programının sonuçlarından türetilmiştir. 


$$
m_{p}=\left(19116 \mathrm{e}^{-9} \cdot \mathrm{F}\right)+\left(2762 \mathrm{e}^{-9} \cdot \mathrm{V}_{\mathrm{e}}\right)+\left(4585 \mathrm{e}^{-9} \cdot \mathrm{T}_{\mathrm{k}}\right)+\left(-2854 \mathrm{e}^{-9} \cdot \mathrm{T}_{\mathrm{d}}\right)+0,004018
$$

Formülde; F ikinci fazın başlangıç noktası olup topuk kısmında olduğu zaman 1 katsayısı dolum ağzında olduğu zaman 2 katsayısı kullanılır. $V_{\mathrm{e}}$ ikinci fazın hızı $(\mathrm{m} / \mathrm{s}), \mathrm{T}_{\mathrm{k}}$ kalıp sıcaklığ $(\mathrm{K}), \mathrm{T}_{\mathrm{d}}$ dökülen ergimiş metalin sıcaklığ $1(\mathrm{~K}), \mathrm{R}$ kalıp yüzeyinin pürüzlülük değeridir ve kalıbın yüzeyi pürüzlü olduğu durumda 1 katsayısı, pürüzsüz olduğu durumda 2 katsayısı kullanılır. $\mathrm{m}_{\mathrm{p}}$ mikro porozite oranı olup hesaplanan değer oluşacak porozite miktarını yüzdesel (\%) olarak vermektedir. Formülün $\left(\mathrm{R}^{2}\right)$ regresyon değeri ise \%97 olarak hesaplanmıştır.

Verilen formüldeki değişkenler Flow3D programında hesaplanan mikro porozite değeri içinde aynı olup formülün $\left(\mathrm{R}^{2}\right)$ regresyon doğruluk değeri \%86 olarak hesaplanmıştır.

$$
m_{p}=\left(-1825 \mathrm{e}^{-5} \cdot F\right)+\left(125 \mathrm{e}^{-6} \cdot \mathrm{V}_{\mathrm{e}}\right)+\left(-161 \mathrm{e}^{-5} \cdot \mathrm{T}_{\mathrm{k}}\right)+\left(-114 \mathrm{e}^{-5} \cdot \mathrm{T}_{\mathrm{d}}\right)+5,39492
$$

Çalışmada elde edilen veriler ile üretilen denklemler sayesinde, enjeksiyon işlemi gerçekleştirilecek parçada oluşacak mikro porozite miktarını hesaplamak mümkündür.

Yapılan çalışma sonucunda kullanılan dişli kutusu modeli için optimum döküm parametreleri; kalıp sıcaklığı 573K, döküm sıcaklığı 1053K, ikinci fazın başlangıç noktası dolum ağzı ve ikinci faz hızı $2 \mathrm{~m} / \mathrm{s}$ olarak belirlenmiştir. Bu parametreler için porozite miktarı Vulcan'da \%2,72 ve Flow3D'de \%3,24 oranında gerçekleşmiştir. Elde edilen sonuçlara göre ideal enjeksiyon şartlarında porozite miktarında \%27 oranında azalma sağlanmıştır.

\section{Teşekkür}

Bu çalışmayı TÜBİTAK 110M537 ve 4001-YL1-14 no'lu projeler ile destekleyen TÜBİTAK ve Süleyman Demirel Üniversitesi BAP Yönetim Birimine teşekkür ederiz.

\section{KAYNAKLAR}

[1] Verran, G., O., Mendes, R. P. K., Rossi, M. A., (2006) Influence of Injection Parameters on Defects Formation in Die Casting Al12Si1,3Cu: Experimental Results and Numeric Simulation. Journal of metarials Processing Technology 179:190-195.

[2] Shoumei, X., Lau F., Lee, W.B., (2002) An efficient thermal analysis system fort he diecasting process. Journals of Materials Processing Technology 128:19-24.

[3] Doehler, H.H., (1974) Basınçlı Döküm. Erkek Teknik Yüksek Öğretmen Okulu Matbaası 514.

[4] Vinarcik, J.E., (2003) High Integrity Die Casting Processes. John Wiley\&Sons 223.

[5] Yüksel, S., Göloğlu C., (2009) Metal enjeksiyon kalıplamada yolluk tasarımı sistematiği, 5. Uluslar arası İleri Teknolojiler Sempozyumu, Karabük Üniversitesi.

[6] Koru, M., (2009) Basınçlı Döküm Yönteminde Al-Si (A413) Alaşımının Termal ve Dinamik Parametrelere Bağlı Olarak Ara Yüzey Isı Transfer Katsayısının Deneysel ve Teorik İncelenmesi. Doktora, Fen Bilimleri Enstitüsü, Süleyman Demirel Üniversitesi, 127.

[7] İpek, O., Koru, M., (2011) Yüksek Basınçlı Döküm Prosesinde Kalıp Sıcaklığına Bağlı Olarak Döküm-Kalıp Ara Yüzeyinde Oluşan Termal Temas Direncinin Belirlenmesi. Is1 Bilimi ve Tekniği Dergisi, 31:45-57.

[8] Imwinkeleid, T., Homberger, H., (2001) Mould Fill Simulation to Improve the Quality of a Component. Magnesium Industry 39-43. 
[9] Çolak, M., Kayıkçı, R., (2005) Döküm simülasyon programları üzerine bir değerlendirme. Metal Dünyas1, 189:2-4.

[10] Arda, İ., Kayıkçı, R., (2006) Döküm simülasyonu nedir? Ne değildir? Metal Dünyası 154:144-148.

[11] Savaş, Ö., Kayıkcı, R., Cüceloğlu, E., (2005) Alüminyum-Silisyum Alaşımlarının Dökümünde Mikro Porozite Probleminin İncelenmesi. Metal Dünyası 144:119-123.

[12] Marques, M.H., (2006) CAE Techniques for casting optimization. Instituto de Engenharia Mecânica e Gestão Industrial 1-4.

[13] Uludağ, A., (2007) Basınçlı Döküm Yönteminde Kalıp Sistem Tasarımı ve Simülasyon Analizi. Yüksek Lisans, Fen Bilimleri Enstitüsü, Yıldız Teknik Üniversitesi 91.

[14] Flender, E., Hartman, G., (2008) Modeling and Simulation in High Pressure Die Casting. Metal World 10-17.

[15] Aslan, O. S., (2007) Basınçlı Dökümde Kaliteyi Etkileyen Faktörlerin Araştırılması. Yüksek Lisans, Fen Bilimleri Enstitüsü, Yıldız Teknik Üniversitesi 84.

[16] Sirviö, M., Vapalahti, S., Väinölä, J., (2007) Complete Simulation of High Pressure Die Casting Process. http://www.castingsimulation.com, 1-6. Available date: 12.08.2014

[17] Jin, C.K., Kang, C.G., (2012) Fabrication by vacuum die casting and simulation of aluminum bipolar plates with mikro-channels on both sides for proton exchange membrane (PEM) fuel cells. International Journal of Hydrogen Energy 32:1661-1676.

[18] Jin, C.K., Kang, C.G., (2011) Fabrication process analysis and exprimental verification for aluminum bipolar plates in fuel cells by vacuum die-casting. Journal of Power Source 196:8241-8249.

[19] Papai, J.P., (1994) Contact heat transfer coefficient in aluminum alloy die casting: an experimental and numerical investigation. Ph. D., The Ohio State University 285. 